\title{
EKSISTENSI DANA BANTUAN OPERASIONAL KESEHATAN (BOK) TERHADAP PENINGKATAN KINERJA PUSKESMAS BULELENG I, KEC. BULELENG, KAB. BULELENG-BALI
}

\author{
Ni Nengah Devi Yuliantini, Putu Lia Cantyawati, Ni Wayan Intan Pratiwi, Ni \\ Wayan Indrayani \\ Jurusan Akuntansi, Universitas Pendidikan Ganesha, Singaraja, Buleleng, Bali
}

\begin{abstract}
Abstrak
Penelitian ini bertujuan untuk menginvestigasi adanya potensi penyimpangan pada organisasi pemerintahan. Investigasi dilakukan dengan menggunakan pendekatan Fraud Triangle pada dinasdinas di Kabupaten Buleleng-Bali. Pengumpulan data dilakukan melalui metode wawancara dan dokumentasi. Hasil penelitian menunjukkan bahwa terdapat potensi kecurangan pengelolaan keuangan akibat kurangnya pengawasan yang dilakukan. Dalam kaitannya dengan Fraud Triangle, inin berhubungan dengan aspek opportunity (kesempatan) yang memungkinkan tindakan kecurangan dapat terjadi.
\end{abstract}

Kata kunci: Fraud triangle; organisasi pemerintahan; Buleleng

Abstract
This study aims to investigate the potential for irregularities in government organizations. Investigations were carried out using the Fraud Triangle approach in agencies in the Regency of Buleleng, Bali. Data collection is done through interviews and documentation. The results showed that there was potential for financial management fraud due to lack of supervision conducted. In connection with the Fraud Triangle, this is related to the opportunity aspect (opportunity) that allows fraud to occur.

Keywords: Fraud triangle; government organization; Buleleng

\section{Pendahuluan}

Pelayanan publik pada dasarnya menyangkut aspek kehidupan yang sangat luas. Dalam kehidupan bernegara, maka pemerintah memiliki fungsi memberikan berbagai pelayanan publik yang diperlukan oleh masyarakat. Puskesmas sebagai pusat pelayanan kesehatan mempunyai dua fungsi, yaitu fungsi pelayanan publik dan fungsi pelayanan klinis/medikal. Kesehatan adalah hak asasi manusia dan sekaligus investasi untuk keberhasilan pembangunan bangsa. Dalam rangka meningkatkan akses pelayanan kesehatan pada masyarakat maka terus dilakukan peningkatan dan pemerataan puskesmas dan jaringannya di semua wilayah. demikia pula dengan upaya kesehatan bersumber daya masyarakat (UKBM), khususnya POSKESDES dan POSYANDU. Meskipun demikian tidak dapat dipungkri bahwa saat ini masih ditemukan berbagai masalah yang dihadapi oleh puskesmas dan jaringannya dalam upaya meningkatkan status kesehatan masyarakat. Beberapa masalah tersebut, salah satu masalahnya adalah pembiayaan untuk pelayanan kesehatan di pusekesmas, khususnya biaya operasional pelayanan yang disediakan oleh pemerintah daerah mampu mencukupi biaya opersional kesehatan puskesmas di daerahnya. Namun, tidak sedikit pula pemerintah daerah yang masih sangat terbatas dalam hal alokasi biaya operasional puskesmas di daerahnya.

Bebrbagai upaya telah dan akan ditingkatkan baik oleh pemerintah daerah maupun pemerintah pusat agar peran dan fungsi puskesmas sebagai fasilitas peayanan kesehatan primer akan semakin meningkat. Beberapa upaya yang dapat dilakukan, salah satu diantaranya dukungan pemerintah pusat akan bertambah dengan diluncurkannya Bantuan Operasional Kesehatan(BOK). BOK sebagai dukungan pembiayaan di puskesmas, ditunjukkan untuk membantu membiayaai berbagai upaya kesehatan yang bersifat promotif dan preventif disamping kegiatan seperti jaminan kesehatan masyarakat(JAMKESMAS) dan jaminan persalinan (JAMPERSAL). Penyaluran damna bantuan operasional kesehatan 
(BOK) merupakan salah satu bentuk tanggung jawab pemerintah dalam pembangunan kesehatan bagi seluruh masyarakat khususnya dalam upaya meningkatkan pencapaian target yang diamanatkan dalam Standar Pelayanan Minimal (SPM) bidag kesehatan, sebagai tolak ukur urusan kewenangan wajib bidang kesehatan yang dilimpahkan oleh pemerintah pusat kepada pemerintah daerah. Puskesmas sebagai salah satu pelaksana pelayanan bidang kesehatan juga mengemban amanat untuk mencapai target tersebut sehingga masyarakat akan mendapat pelayanan kesehatan yang semakin merata, berkuaitas, dan berkeadilan.

Bantuan Operasional Kesehatan (BOK) merupakan salah satu program unggulan kementrian kesehatan. BOK merupakan upaya pemerintah untuk membantu daerah dalam mencapai target nasional bidang kesehatan yang menjadi kewenagan wajib daerah, karena tidak semua kabupaten/kota memunyai kecukupan anggaran atau kepedulian untuk membiayaai pembangunan kesehatan, khususnya di puskesmas. Dimana puskesmas sangat penting karena menjadi ujung tombak dalam upaya kesehatan dimasyarakat, terutama upaya promotif dan preventif. Bantuan operasioanal kesehatan (BOK) secara khus dimaksudkan untuk meningkatakan kinerja puskesmas dan jejaringnya, serta poskesdes dan posyandu. BOK mendorong agar puskesmas mampu mengidentifikasi permasalahan kesehatan diwilayah kerjanya melui lokakarya mini, selanjutnya disusun rencana kegiatan untuk mengatasi masalah tersebut. Peningkatan kinerja puskesma, poskesdes, dan posyandu tentu akan berdampak posifit bagi masyarakat yang dilayani. Realisi BOK telah dimulai pada pertengahan tahun 2010 dan terus ditingkatkan pada tahun-tahun berikutnya. $\mathrm{Hal}$ ini nyata dari komitmen dan realisi bantuan pemerintah pusat kepada daerah yang terus meningkat. Pemerintah pusat tetap meningkatkan bahwa Bantuan Operasional Kesehatan bersifat suplemen dalam arti tidak dijadikan sumber pembiayaan utama bidang kesehatan di suatu wilayah, oleh karena itu komitmen dan tindakan nyata Pemerintah Daerah tetap diperlukan untuk mengalokasikan anggaran kesehatan yang memadai terutama untuk upaya promotif dan preventif.

Meningkatnyadana BOK harus selaras dengan pengelolaan yang transparan dan akuntabel. Bok harus dimanfaatkan secara optimal, karena Bok dapat dipergunakan untuk seluruh program kesehatan yang bersifat promotif-preventif. Sangat diharapkan peran dinas kesehatan kabupaten/kota untuk mengkoordinasikan, membina, dan mengawasi, agar dana BOK digunakan secara efektif, efisien, dan akuntabel dalam mendorong pemanfaatan dana BOK yang maksimal. Sejak diluncurkannya dana Bantuan Operasional Kesehatn (BOK), telah banyak dilakukan penyempurnaan, seperti kebijakan mekanisme penyaluran dana, pengorganisasian, ruang lingkup BOK dan sebagainya. Masing -masing puskesmas memiliki program kerja yang berbeda uniknya di puskesmas Buleleng I melaksanakan program "PKPR (Pelayanan Kesehatan Peduli Remaja) Terhadap Kesehatan Reproduksi Remaja di Kecamatan Buleleng". Melalui program PKPR yang dilaksanakan puskesmas Buleleng I tentunya akan memerlukan dana BOK untuk menunjang kegiatan-kegiatan demi menyukseskan program tersebut.

Berdasarkan uraian diatas maka penulis berminat melakukan peneitian, untuk melihat ada atau tidaknya peningkatan kinerja di Puskesmas Buleleng I setelah adanya dana Bantuan Operasional Kesehatan dengan membandingkan kinerja puskesmas sebelum dan sesudah adanya dana Bantuan Operasional Kesehatan (BOK) dengan judul: "Eksistensi Dana Bantuan Operasional Kesehatan (BOK) Terhadap Peningkatan Kinerja Puskesmas Buleleng I, Kec. Buleleng,Kab. Buleleng-Bali”.

\section{Metode}

\section{Tempat dan Waktu Penelitian}

Penelitian ini dilaksanakan di Puskesmas Buleleng I yang berlokasi di jalan A. Yani No. 43 Singaraja. Waktu yang digunakan dalam penelitian ini adalah 21 Mei 2018.

\section{Jenis dan Sumber Data}

1. Dalam penelitian ini kami menggunakan pendekatan kualitatif, karena pendekatan ini sesuai dengan objek pokok permsalahan yang akan kami teliti. Penelitian ini, 
memerlukan pengamatan dan pemahaman yang cermat dan seksama terhadap objek penelitian.

2. Dalam penelitian ini sumber data yang kami gunakan yaitu sumber data sekunder. Sumber data sekunder merupakan sumber data penelitian yang diperoleh melalui media perantara atau secara tidak langsung yang berupa buku, catatan, bukti yang telah ada, atau arsip baik yang dipublikasikan maupun yang tidak dipublikasikan secara umum. Data sekunder disajikan oleh pihak pengumpul data primer, data jenis ini dapat juga berupa Undang-Undang dan Peraturan yang terkait dengan dana BOK.

\section{Metode Pengumpulan Data}

Menurut Sugiono (2009) bahwa pengumpulan data diperoleh dari hasil observasi, wawancara, dokumentasi dan gabungan/triangulasi. Dalam penelitian ini agar memperoleh data yang valid dan dapat dipertanggungjawabkan maka kami menggunakan teknik penggumpulan data dengan cara observasi, wawancara, dan dokumentasi. Metode pengumpulan data yang kami gunakan, antara lain :

1. Metode observasi, merupakan teknik pengumpulan data yang tidak hanya wawancara dan angket saja, namun juga menggunakan berbagai kondisi dan situasi yang telah terjadi.

2. Metode wawancara, merupakan teknik pengumpulan data yang dilakukan dengan cara tatap muka dan Tanya jawab langsng kepada narasumber atau informan. Dalam melakukan wawancara yang kami lakukan adalah wawancara yang tidak berstruktur, dimana arah pertanyaannya lebih terbuka, namun tetap focus sehingga akan diperoleh informasi yang lebih luas.

3. Metode dokumentasi, merupakan metode yang didapatkan melalui catatancatatan hasil dari wawancara di Puskesmas Buleleng I, foto-foto dan arsip yang ada pada Puskesmas Buleleng I.

4. Metode kepustakaan, merupakan metode pengumpulan data yang kami lakukan dengan cara membaca dan merangkum materi dari jurnal, dan sumber informasi lainnya yang berhubungan dengan BOK dalam Puskesmas Buleleng

\section{Metode Analisis Data}

Metode analisis yang kami gunakan yaitu metode kualitatif karena metode kualitatif sesui dengan pendekatan studi kasus kami, sehingga analisis data yang digunakna dengan cara menelaah jawaban-jawaban yang kami dapat dari objek penelitian.

\section{Definisi Operasinal}

Definisi operasional variabel merupakan pengertian variabel yang telah diungkap pada definisi konsep secara operasional, praktik, nyata dalam lingkungan objek penelitian atau yang telah diteliti. Variabel yang digunakan dalam penelitian kami yaitu variabel bebas karena variabel bebas merupakan variabel yang mempengaruhi, yang menyebabkan berubahnya variabel terkait.

\section{Hasil dan Pembahasan Gambaran Umum}

Puskesmas Buleleng 1 terletak di jalan A. Yani, Singaraja, Kecamtan Buleleng, Kabupaten Buleleng, Provinsi Bali. Puskesmas Buleleng 1 memiliki wilayah kerja 16 Desa 45.497 ribu penduduk, dengan tiga dokter umum, satu dokter gigi, Sembilan perawat, satu perawat gigi, empat belas bidan, satu farmasi, lima kesehatan masyarakat, tiga kesehatan lingkungan, dua gizi, tujuh tenaga non kesehatan. Puskesmas Buleleng 1 memiliki sejumlah kegiatan diantaranya adalah PKPR. Dimana PKPR ini adalah suatu pelayanan kesehatan Peduli Remaja yang mana di biayai oleh dana BOK. Kegiatan PKPR yaitu memberikan layanan pencegahan (preventif), pengobatan (kuratif), promosi dan rehabilitasi, puskesmas PKPR juga menjalankan kegiatan seperti :

1. Pemberian informasi dan edukasi 
2. Pelayanan klinis medis (termasuk pemeriksaan penunjang \& rujukan)

3. Konseling

4. Pelatihan konselor sebaya

Yang mana layanan kesehatan yang disediakan secara umum adalah :

1. Pemeriksaan kehamilan remaja

2. Konseling semua masalah kesehatan reproduksi dan seksual

3. HIV/AIDS

4. Infeksi Menular Seksual (IMS)

5. Konseling mengenai masalah kejiwaan

6. Anemia

Ini semua bisa didapatkan di puskesmas yang menyediakan program PKPR. Jika remaja-remaja igin bergabung pada PKPR ini datang saja ke puskesmas terdekat. Selain membantu pihak puskesmas,bisa juga membantu kegiatan masyarakat di desa desa.

Upaya kesehatan prioritas bersumber dana BOK dilakukan di Puskesmas adalah implementasi kegiatan dari upaya kesehatan promotif dan preventif dalam mencapai target tujuannya. Keguatan prioritas yang dilakukan puskesmas diantaranya itu:
1. Pendidikan Gizi
2. Pelayanan Gizi
3. Tata Laksana Gizi
4. Pelayanan Kesehatan Bayi
5. Pelayanan Kesehatan Balita
6. Pelayanan Kesehatan Ibu Hamil
7. Pelayanan kesehatan ibu nipas
8. Pelayanan keluarga berencana (KB)
9. Upaya mengendalikan penyebaran dan penurunan jumlah kasus baru HIV/AIDS
10. Upaya mewujudkan akses terhadap pengobata HIV/AIDS bagi yang membutuhkan.
11. Upaya pengendalian penyebaran dan menurunkan jumlah kasus baru malaria dan TB
12. Serta kegiatan lain yang berdaya ungkit tinggi terhadap pencapaian tujuan puskesmas

Upaya kesehatan promotif dan preventif, bersumber dana BOK yang dilakukan PUSKESMAS Buleleng I seperti upaya pengendalian penyebaran dan penurunan jumah kasus baru HIV/AIDS. Berdasarakan hasil wawancara mendalam mengenai program BOK dalam menunjang terwujudnya akses terhadap pengobatan HIV/AIDS bagi semua yang membutuhkan. Untuk mewujudkan akses terhadap pengobatan HIV/AIDS bagi semua yang membutuhkan hanya dilakukan rujukan kerumah sakit, jadi dapat disimpulkan hanya tindakan pencegahan yang dapat dilakukan.

\section{Upaya kesehatan lainnya.}

Berdasarkan hasil penelitian bahwa upaya kesehatan lainnya pada buleleng I yang sumber dananya dari bantuan operasional kesehatan (BOK) yaitu antara lain seperti, Posyandu, PKPR (pelayanan kesehatan peduli remaja), dan kegiatan lainnya yang dilakukan sesuai dengan petunjuk teknis

\section{Ruang lingkup pemanfaatan}

1. Transportasi kegiatan

A. Transportasi petugas kesehatan

Dana BOK dimanfaatkan untuk transportasi petugas kesehatan untuk melakukan upaya kesehatan seperti ke posyandu,dan telah ditentukan besarnya biaya untuk kegatan tersebut sesuai dengan petunjuk teknis. Dalam mengalokasikan dana BOK tersebut disesuaikan dengan kondisi wilyah setempat dan kebutuhannya.

B. Transportasi kader kesehatan 
Dana BOK juga dimanfaatkan juga untuk transporasi kader kesehatan karena peran kader sangat penting dalam pembangunan kesehatan yaitu bertugas bermotifasi dan mengorganisasikan masyarakat serta melakukan pendampingan terhadap masyarakat (Hartono,2011)

\section{Pembelian atau belanja barang}

Dana BOK juga dimanfaatkan dalam pemebelian ATK, PMT,penyuluhan , fotocopy,sampai pembelian konsumsi untuk rapat.

\section{Kinerja pelayanan puskesmas setelah adanya dana BOK}

Dari hasil penilitan dan pengamatan yang kami lakukan pada puskesmas buleleng 1 terlihat bahwa kinerja dan pelayanan pada puskesmasbuleleng 1,sangat terbantu dengan adanya dana BOK. Dana BOK ini dapat membantu jalnanya kegiatan - kegiatan yang dilaksanakan oleh puskesmas buleleng 1. Dilihat juga dari banyaknya kunjungan pasien yang mempercayakan kesehatannya pada puskesmas buleleng 1. Selain itu pengnjung juga merasa nyaman atas pelayanan yang diberikan oleh pegawai-pegawaii yang bekerja pada puskesmas tersebut. Seperti adanya pegawai yang sigap melayani pasien yang ingin berobat tanpa kata lelah bagi pegawai tersebut untuk melayani masyarakat.

\section{Simpulan dan Saran}

Berdasarkan hasil penelitian yang kelompok kami lakukan dapat disimpulkan bahwa, adanya dana BOK memberikan pengaruh yang sangat signifikan terhadapa kinerja, maupun pelayanan yang di berikan oleh Puskesmas Buleleng 1. Hal itu dilihat dari, program-program kerja yang dicanangkan dan direalisasikan oleh puskesmas Buleleng satu sebagai tempat pelayanan kesahatan masyarakat. Program-program kerja yang dibantu oleh dana BOK dan telah direalisasikan oleh puskesmas Buleleng 1 seperti PKPR yang diperuntukan kepada remaja-remaja di daerah Buleleng 1.

Adapun saran yang dapat kami sampaikan sehubungan dengan permasalahan di atas diaharapkan pihak puskesmas atau yang terkait tidak terlalu bergantung dengan dana BOK. Sebaiknya dana BOK dapat dipertaggung jawabkan akuntablenya atau transparansi dana BOK tersebut.

\section{DAFTAR PUSTAKA}

Humas. 2016. Hipotesis Asosiatif. http://penalaran-unm.org/hipotesid-asosiatif. Diakses 27 Mei 2018

Gulo W. 2000. Metodelogi Metode Penelitian. Grasindro: Jakarta. Dikutip 27 Mei 2018

Sugiyono. 2009. Metode Penelitian Bisnis. Penerbit Alfabeta: Bandung 